\title{
Experimental protein and energy deficiencies: effects on brain free amino acid composition in rats
}

\author{
BY M. KALADHAR AND B.S. NARASINGA RAO \\ National Institute of Nutrition, \\ Indian Council of Medical Research, \\ Hyderabad-500007, India
}

(Received 13 January 1977 - Accepted 17 March 1977)

1. The effects of protein-energy malnutrition on brain free amino acids of acidic and neutral groups were investigated in experimental rats.

2. Severe energy restriction did not modify the free amino acid composition of the brain while protein deficiency affected certain amino acids of the brain in opposite directions. Significant decreases in the levels of aspartic acid, threonine and tyrosine were observed in the protein-deficient rats.

3. These changes in brain amino acids appear to be specific to protein deficiency and not affected by energy deficiency.

Kwashiorkor and marasmus are the two major clinical forms of protein-energy malnutrition among preschool children. Protein-energy malnutrition has been shown to produce profound behavioural deficiencies, both in children (Scrimshaw, 1967; Cravioto \& De Licardie, 1968; Monckeberg, 1968) and in experimental animals (Frankova, \& Barnes, 1968 $a, b$; Levitsky \& Barnes, 1970). Although information on the biochemical changes in the central nervous system underlying such behavioural changes in protein-energy malnutrition is limited, altered metabolism of neurotransmitter substances in the brain could be one important consideration (Shoemaker \& Wurtman, 1973). Since some amino acids are either precursors of amine neurotransmitter substances (e.g. tyrosine for dopamine and norepinephrine and tryptophan for serotonin) or have neurotransmitter functions attributed to them (e.g. aspartic acid, glutamic acid, glycine, etc. (De Feudis, 1975)), a study was undertaken to examine the sensitivity of the brain free amino acid pool to severe dietary deficiencies of protein and energy in experimental rats.

\section{METHODS}

The experimental model described by Ramanadham \& Kaplay (1975) was employed to induce protein-energy malnutrition in rats. Male Wistar rats of the Institute colony were maintained on $18 \%$ protein diet from weaning until they attained an average body-weight of $93 \pm 1 \mathrm{~g}$. They were then divided into three groups using randomized block design. Animals of groups 1 and 3 were given the high- and the low-protein diets respectively ad lib., while animals of group 2 were given restricted amounts of the high protein diet, so as to maintain body-weights similar to those of animals in group 3 . The composition of diets used is given in Table 1. The animals were fasted overnight before being killed after 7-9 weeks on their respective diets. The rats given the low protein diet were killed after the onset of oedema, which was observed 7-9 weeks after the start of the experiment. One rat from each group was killed at a given point of time, brains quickly removed, precipitated with sulphosalycylic acid and protein-free filtrates prepared according to the method described by Enwonwu \& Worthington (1973). Free amino acids in the protein-free filtrates were determined in an automatic amino acid analyser using PA Beckman BA-35 resin. 
Table 1. Composition (\%) of the high-and low-protein diets given to rats

Ingredient

Casein*

Starch

Sucrose

Seseme oil

Salt mixture

Vitamin mixture $\ddagger$

Choline chloride

Vanitin§
High protein

$22 \cdot 1$

$31 \cdot 1$

$31 \cdot 1$

$10 \cdot 0$

$5 \cdot 0$

$0 \cdot 50$

$0 \cdot 20$

0.008
Low protein

1.0
41.65
41.65
10.0
5.0
0.50
0.20
0.008

- Casein used in the present experiment contained $80 \%$ protein.

+ Horwitz (1965).

$\ddagger$ Vitamin mixture from Evaluation of protein quality, no. 1100 NAS-NRC (1963).

$\$$ Vanitin is a vitamin $A$ and $D$ rich oil preparation of Roche Products Ltd, Bombay. It contains ( $/ 100 \mathrm{~g}$ oil): $12.5 \times 10^{8}$ I.U. vitamin $A$ and $1.0 \times 10^{6}$ 1.U. vitamin D.

Table 2. Free amino acid concentrations ( $\mu$ mollg wet tissue) in the brains of rats aged 7-9 weeks given high-and low-protein diets*

(Values are given as mean \pm SEM of six rats. Nos. in parentheses indicate values as percentage of controls)

\begin{tabular}{|c|c|c|c|c|c|c|c|c|}
\hline \multirow[b]{2}{*}{ Parameters } & \multicolumn{2}{|c|}{$\begin{array}{l}\text { High-protein } \\
\text { ad. lib } \\
\text { (1) }\end{array}$} & \multicolumn{2}{|c|}{$\begin{array}{l}\text { High-protein } \\
\text { restricted } \\
\text { (2) }\end{array}$} & \multicolumn{2}{|c|}{$\begin{array}{l}\text { Low-protein } \\
\text { ad. lib } \\
\text { (3) }\end{array}$} & \multicolumn{2}{|c|}{$\begin{array}{c}\text { Statistical } \\
\text { significance } P \text { value } \\
\text { (between groups) }\end{array}$} \\
\hline & Mean & SE & Mean & SE & Mean & SE & 1 vs 2 & 1 vs 3 \\
\hline Body-weight (9) & 229 & 7 & 58 & $1 \cdot 2$ & 51 & $1 \cdot 3$ & & \\
\hline Brain weight (9) & $1 \cdot 75$ & 0.02 & $1 \cdot 56$ & 0.02 & $1 \cdot 49$ & 0.01 & $<0.001$ & $<0.001$ \\
\hline \multicolumn{9}{|l|}{ Amino acids } \\
\hline Aspartic acid & 1.93 & $0 \cdot 10$ & $1 \cdot 69$ & $0.20(99)$ & $1 \cdot 17$ & $0.14(61)$ & 一 & $<0.001$ \\
\hline Threonine & 0.66 & 0.06 & 0.56 & $0 \cdot 10(85)$ & 0.26 & $0.02(39)$ & - & $<0.001$ \\
\hline Serine & 0.65 & 0.03 & 0.64 & $0.11(98)$ & 0.64 & $0.04(98)$ & - & - \\
\hline Glutamine & $10 \cdot 4$ & 0.48 & $10 \cdot 0$ & $1.65(96)$ & 8.43 & $1.02(81)$ & 一 & - \\
\hline Glycine & $1 \cdot 18$ & 0.09 & $1 \cdot 05$ & $0.13(89)$ & $1 \cdot 27$ & $0 \cdot 21(108)$ & - & - \\
\hline Alanine & 0.49 & 0.02 & 0.43 & $0.07(88)$ & 0.54 & $0 \cdot 10(110)$ & 一 & - \\
\hline Valine & 0.073 & 0.009 & 0.071 & $0.015(97)$ & 0.087 & $0.03(110)$ & - & 一 \\
\hline Methionine & 0.049 & 0.009 & 0.051 & $0.004(104)$ & 0.041 & $0.01(84)$ & - & 一 \\
\hline Isoleucine & 0.041 & 0.002 & 0.042 & $0.005(102)$ & 0.035 & $0.007(85)$ & - & 一 \\
\hline Leucine & 0.079 & 0.006 & 0.072 & $0.011(91)$ & 0.059 & $0.015(75)$ & - & - \\
\hline Tyrosine & 0.049 & 0.003 & $0 \cdot 044$ & $0.003(90)$ & 0.031 & $0.004(63)$ & - & $<0.01$ \\
\hline Phenylalanine & 0.038 & 0.004 & 0.037 & $0.006(97)$ & 0.048 & $0.008(126)$ & - & - \\
\hline Tyrosine: Phenylalanine & 1.37 & 0.13 & $1 \cdot 28$ & 0.14 & 0.79 & 0.20 & 一 & $<0.05$ \\
\hline
\end{tabular}

\footnotetext{
* For details of diets, see Table 1.
}

\section{RESULTS}

The results on brain weights and free amino acids are shown in Table 2. Statistically significant decreases in brain weights were observed both in the high-protein restricted control and low protein groups when compared to the high-protein ad lib. fed group.

Only the acidic and neutral amino acids were determined in the present study. The rats given the low protein diet ad lib. for 7-9 weeks showed significant decreases in their brain amino acid levels of aspartic acid (39\%), threonine $(61 \%)$ and tyrosine $(37 \%)$ when compared to rats given the high-protein diet ad lib. The levels of glutamic acid, methionine, isoleucine and leucine also tended to be lower while the levels of alanine, valine and phenylalanine tended to be higher in the brains of rats given the low-protein diet when compared to rats given the high-protein diet ad lib. However, these differences 
were not statistically significant. In contrast to the changes observed in the rats fed the low-protein diet, feeding restricted amounts of a high-protein diet to rats did not show any significant difference in the free amino acid composition of the brain when compared to rats given high-protein diet ad lib. However, levels of aspartic acid, glycine, threonine and alanine tended to be lower in these rats.

\section{DISCUSSION}

The results obtained in the present study indicate that protein deficiency in experimental rats affects the brain free amino acid composition by decreasing the concentrations of some amino acids like aspartic acid, threonine, tyrosine, etc., and also by increasing the concentrations of some amino acids like phenylalanine, although the changes in the latter direction were less striking. In contrast, feeding a high-protein diet in restricted amounts, so as to keep the body-weights of the rats comparable to the protein-malnourished rats, did not affect the brain free amino acid composition significantly. However, feeding rats with either a low-protein diet $a d$ lib. or a high-protein diet in restricted amounts, results in a marked reduction in their brain weights relative to those of rats given a high-protein diet $a d$ lib., thus suggesting that both severe protein deficiency and severe energy restriction might affect the growth of the brain.

Anthony \& Edozien (1975) have reported changes in serum amino acids in proteinenergy malnourished rats; levels of acidic and neutral amino acids, with the exception of serine, were decreased in the serum of protein-deficient rats. However, serum amino acids might not have a direct bearing on the amino acid levels in tissues especially like the brain where the free amino acid profile is under strong haemostatic control (Lajtha, 1968). Of the several amino acids reported to decrease in the serum of protein-deficient rats, in the brain tissue, only aspartic acid, threonine and tyrosine also showed a significant decrease, while glutamic acid, isoleucine and leucine showed a marginal decrease in the present study. The brain free amino acids of rats showed remarkable stability to severe restriction of energy, while Anthony \& Edozien (1975) observed similar decreases in serum amino acids in both energy-restricted and protein-deficient rats. Although the reasons are not quite clear, it must be pointed out that the energy-restricted rats of Anthony \& Edozien (1975) were also severely protein-malnourished (since the protein level in their diets was only $1 \%$, while energy-restricted rats in our experiments received a higher level of protein (18\% protein diet).

Earlier Enwonwu \& Worthington (1973) reported changes in brain free amino acids in their monkey model of kwashiorkor. The changes in brain acidic amino acids of the monkey model appear to be in general agreement with our rat model of kwashiorkor, although the magnitude of the decreases are different. There were significant increases reported in brain phenylalanine and tyrosine of protein-deficient monkeys, while in protein-deficient rats we observed a marginal increase in phenylalanine and a significant decrease in tyrosine. Whether changes in brain free amino acid profile in experimental kwashiorkor could be somewhat different in different species is speculative. Also, Badger \& Tumbleson (1974) demonstrated in piglets that changes in brain amino acid concentrations could be related to other important factors such as the age of onset of proteinenergy malnutrition.

Free amino acids in the brain are important for the maintenance of cell structure and ionic balance and as precursors for neuroregulatory substances (McIlwain \& Bachelard, 1971). A decrease in brain tyrosine might result in a decrease in brain norepinephrine levels and thus affect synaptic transmission in noradrenergic neurons of the brain. Aspartic acid is known to be a neuro-excitory amino acid (De Feudis, 1975), and therefore its 
decrease in the brain of protein-malnourished rats might affect the neuro-excitory functions due to aspartic acid. Absence of such changes in the energy-restricted control rats suggest that these effects are specific to protein deficiency. The present findings in experimental kwashiorkor could be of some relevance to the behavioural changes observed in malnourished children and experimental animals.

We thank Dr S. G. Srikantia, Director, National Institute of Nutrition, for his helpful discussions during the course of the study.

\section{REFERENCES}

Anthony, L. E. \& Edozien, J. C. (1975). J. Nutr. 105, 631.

Badger, T. M. \& Tumbleson, M. E. (1974). J. Nutr. 104, 1329.

Cravioto, J. \& De Licardie, E. (1968). In Malnutrition, Learning and Behaviour, pp. 252-269 [N. S. Scrimshaw and J. E. Gordon, editors]. Cambridge, Mass.: M.I.T. Press.

De Feudis, F. V. (1975). Ann. Rev. Pharmacol, Palo Alto, Calif. 5, 105.

Enwonwu, C. O. \& Worthington, B. S. (1973). J. Neurochem. 21, 799.

Frankova, S. \& Barnes, R. H. (1968a). J. Nutr. 96, 477.

Frankova, S. \& Barnes, R. H. (1968b). J. Nutr. 96, 485.

Horwitz, W. (editor) (1965). Official Methods of Analysis, 10th ed, p. 779. Washington, D.C.: Association of Official Agriculture Chemistry.

Lajtha, A. (1968). In Progress in Brain Research, vol. 29, pp. 201-216 [Lajtha, A. \& Ford, D. H., editors]. Amsterdam: Elsevier.

Levitsky, D. \& Barnes, R. H. (1970). Nature, Lond. 225, 465.

McIlwain, H. \& Bachelard, H. S. (1971). In Biochemistry and the Central Nervous System, 4th ed., pp. 266307. Edinburgh: Churchill-Livingstone.

Monckeberg, F. (1968). In Malnutrition, Learning and Behaviour, pp. 269-278. [N. S. Scrimshaw \& J. E. Gordon, editors]. Cambridge, Mass.: M.I.T. Press.

Ramanadham, M. \& Kaplay, S. S. (1975). Nutr. Rep. Int. 12, 93.

Scrimshaw, N. S. (1967). Am. J. Clin. Nutr. 20, 493.

Shoemaker, W. J. \& Wurtman, R. J. (1973). J. Nutr. 103, 1357. 